\title{
Amino acid variants of the vitamin D-binding protein and risk of diabetes in white Americans of European origin
}

\author{
Tomasz Klupa ${ }^{1,2,3}$, Maciej Malecki ${ }^{1,2,3}$, Linda Hanna ${ }^{1}$, Joanna Sieradzka ${ }^{3}$, Jakub Frey ${ }^{3}$, James H Warram ${ }^{1}$, \\ Jacek Sieradzki $^{3}$ and Andrzej S Krolewski ${ }^{1,2}$ \\ ${ }^{1}$ Research Division, Joslin Diabetes Center, Boston, Massachusetts, USA, ${ }^{2}$ Department of Medicine, Harvard Medical School, Boston, Massachusetts, \\ USA, ${ }^{3}$ Department of Metabolic Diseases, School of Medicine, Jagiellonian University, Cracow, Poland \\ (Correspondence should be addressed to A S Krolewski, Section on Genetics \& Epidemiology, Joslin Diabetes Center, One Joslin Place, Boston, \\ Massachusetts 02215-5397,USA; Email: Akrolewski@joslin.harvard.edu)
}

\begin{abstract}
Background: Genetic variants of vitamin D-binding protein (DBP) have been reported to be associated, not only with diabetes, but also with prediabetic traits, in several populations. There are two known polymorphisms in exon 11 of the DBP gene that result in amino acid variants: at codons 416 $\mathrm{GAT} \rightarrow$ GAG $($ Asp $\rightarrow$ Glu $)$ and 420 ACG $\rightarrow$ AAG $(\mathrm{Thr} \rightarrow$ Lys $)$.

Objective: To examine the association of these polymorphisms with diabetes in white Americans of European origin.

Methods: We studied unrelated individuals: 181 with type 1 diabetes, 215 with type 2 diabetes, and 163 healthy controls. Exon 11 was amplified using polymerase chain reaction and the two alleles were determined by digestion with specific endonucleases: HaeIII and StyI, respectively.

Results: At codon 416. Asp/Glu allele frequencies were $45 \% / 55 \%$ in patients with type 1 diabetes, $43 \% / 57 \%$ in patients with type 2 diabetes, and $46 \% / 54 \%$ in controls $\left(\chi^{2}=0.69,2\right.$ d.f., $\left.P<0.71\right)$. At codon 420 , corresponding Lys/Thr frequencies were $27 \% / 73 \%, 30 \% / 70 \%$, and $30 \% / 70 \%\left(\chi^{2}=1.25\right.$, 2 d.f., $P=0.53)$. Distributions of genotypes at both loci, and the haplotypes defined by the two loci, were also very similar in all groups.

Conclusion: DNA polymorphisms in the DBP gene are not associated with diabetes in white Americans of European origin.
\end{abstract}

European Journal of Endocrinology 141 490-493

\section{Introduction}

There is circumstantial evidence that the vitamin D pathway is involved in the development of diabetes. The $\beta$-cells contain a receptor for the 1,25-dihydroxyvitamin $\mathrm{D}_{3}$ and the concentrations of this steroid in serum may have impact on insulin secretion (1). For example, a correlation between serum concentrations of vitamin $\mathrm{D}$ and insulin secretion was described in an elderly Dutch population (2), and in the population of Asian immigrants living in the United Kingdom, supplementation with this vitamin improved insulin secretion (3). Vitamin D also has immunomodulatory properties: it has an important role in inflammatory reactions, and can prevent the development of insulitis in an animal model (4). Recently, associations have been described between allelic variants of the vitamin D receptor gene and type 1 diabetes and impaired insulin secretion in a population at risk of type 2 diabetes $(5,6)$.

In Pima Indians, linkage has been reported between prediabetic metabolic traits and a few microsatellite markers on chromosome $4 \mathrm{q}$ in the region containing the vitamin D-binding protein (DBP) gene (known also as the Gc locus component) (7). DBP is essential for vitamin D cellular endocytosis and metabolism (8), thus variants of the DBP protein may affect the amount of active vitamin $\mathrm{D}$ in $\beta$-cells and, subsequently, insulin secretion. Two frequent polymorphisms in exon 11 of this gene result in amino acid changes (9): a nucleotide substitution in codon 416 , from GAT to GAG, replaces aspartic acid with glutamic acid, and a nucleotide substitution in codon 420, ACG to AAG, replaces threonine with lysine. In several populations, these polymorphisms are associated with insulin secretion $(10,11)$. They were also associated with type 2 diabetes in Polynesian Island populations (12). A small study in a white population showed a borderline association of these polymorphisms and type 1 diabetes (13).

The aim of the present study was to examine the associations of amino acid variants at codons 416 and 420 of the DBP gene with type 1 and type 2 diabetes in white Americans of European origin. 


\section{Participants and methods}

DNA for this study was available from 163 unrelated control individuals with normal glucose tolerance, 181 unrelated patients with type 1 diabetes, and 215 unrelated patients with type 2 diabetes. All individuals were white Americans of European origin, residents of Massachusetts, USA, and were examined at the Joslin Diabetes Center in connection with two current research projects. Both projects were approved by the Human Subjects Committee at the Joslin Diabetes Center.

Individuals with type 1 diabetes were examined as part of a current study of the natural history of microalbuminuria (14). For this study, we selected individuals with insulin-dependent diabetes diagnosed before age 30 years who, at the time of examination, had diabetes for 15 years or more. Individuals with type 2 diabetes were selected from among patients who had diabetes diagnosed between ages 35 and 69 years and participated in a study of the genetics of type 2 diabetes. Diabetes was diagnosed according to WHO criteria (15), and was considered type 2 if the individual was treated with diet or oral agents for at least 2 years after the diagnosis. Non-diabetic controls were recruited from among spouses of patients with type 2 diabetes participating in the study of the genetics of type 2 diabetes. All controls had no clinical history of diabetes and had normal fasting blood glucose evaluated according to current American Diabetic Association (ADA) criteria (16).

DNA was extracted from blood using standard procedures. Specific primers were designed to amplify exon 11 and parts of the flanking introns (forward primer: CAAGTCTTATCACCATCCTG; reverse primer: GCCAAGTTACAATAACACCAG) on the basis of the published DBP gene sequence (GenBank accession numbers: L10641, L10642). The total length of the PCR product was 809 base pairs (bp). If the GAG (glutamic acid) variant at codon 416 is present, the expected lengths of HaeIII digestion products are $571 \mathrm{bp}$ and $238 \mathrm{bp}$. If the AAG (lysine) variant at codon 420 is present, the expected lengths of StyI digestion products are $578 \mathrm{bp}$ and $231 \mathrm{bp}$.

The PCR reaction was performed in a 96-well plate thermal cycler (PTC-100, MJ Research Inc., Las Vegas, NV, USA). The volume of PCR reaction was $50 \mu \mathrm{l}$. Each PCR reaction contained $100 \mathrm{ng}$ genomic DNA, $35 \mathrm{pmol}$ each primer, $200 \mu \mathrm{mol} / \mathrm{l} \mathrm{dNTP,} 1.0 \mathrm{mmol} / \mathrm{l} \mathrm{MgCl}_{2}$ and 1.0 units TaqGold polymerase (Perkin Elmer, Foster City, CA, USA) with $5.0 \mu \mathrm{l} 10 \times$ PCR buffer. We used the following PCR conditions: denaturation at $94^{\circ} \mathrm{C}$ for $10 \mathrm{~min}$, followed by 39 cycles of denaturation for $1 \mathrm{~min}$ at $94^{\circ} \mathrm{C}$, annealing at $54^{\circ} \mathrm{C}$ for $1 \mathrm{~min}$ and extension at $72^{\circ} \mathrm{C}$ for $1 \mathrm{~min}$, with a final extension at $72^{\circ} \mathrm{C}$ for $10 \mathrm{~min}$. PCR products were digested separately with HeaIII and StyI endonucleases according to the supplier's recommendation. Restriction fragment length polymorphisms were separated on $2 \%$ agarose gel, stained by ethidium bromide and photographed.

Allele frequencies were determined from the genotype frequencies. The Asp/Glu and Thr/Lys variants jointly determine four possible haplotypes (Asp-Thr, Asp-Lys, Glu-Thr, and Glu-Lys). Haplotype frequencies and the linkage disequilibrium coefficient between the two polymorphisms was computed using the $\mathrm{EH}$ program (ftp://linkage.rockefeller.edu/software/eh). Under the assumptions of the Hardy-Weinberg equilibrium and random mating, this iterative procedure yields maximum likelihood estimates of the haplotype frequencies in the study population, on the basis of the joint distribution of the two polymorphic markers. The phase is unknown for individuals with doubly heterozygous genotypes, but the conditional probabilities of the alternative haplotype configurations can be calculated from the estimated haplotype frequencies. For markers in significant linkage disequilibrium, the difference between the conditional probabilities may be so large that haplotypes can be assigned to phase-unknown individuals with a high degree of confidence (17). For double heterozygotes in this study ( 54 controls, 49 type 1 patients, and 76 type 2 patients), the conditional probability of the haplotype pair 'Asp-Lys/Glu-Thr' was greater than 0.99, regardless of whether it was estimated in each group separately or in the total group. Therefore, all double heterozygotes were assumed to have this pair of haplotypes. For individuals homozygous at both loci (67 controls, 74 type 1 patients, and 87 type 2 patients) or heterozygous at only one locus ( 42 controls, 58 type 1 patients, and 52 type 2 patients), haplotypes can be determined directly.

Differences in allele, genotype and haplotype distributions in the study groups were examined by $\chi^{2}$ test. Differences in quantitative traits were assessed using ANOVA. Data analysis was performed using SAS Version 6.12 (SAS Institute, Cary, NC, USA).

\section{Results}

The clinical characteristics of patients with diabetes and control subjects are summarized in Table 1. Among type 1 patients there were 68 persons with normoalbuminuria and 113 with proteinuria. As their characteristics were similar, only combined data are presented. The group of patients with type 2 diabetes was significantly more obese in comparison with the other groups.

Altogether, 568 individuals were genotyped for the Asp/Glu polymorphism at codon 416 and the Thr/Lys polymorphism at codon 420. Genotypes for both loci were in Hardy-Weinberg equilibrium in all three groups separately and in the total group. The two polymorphisms were in strong linkage disequilibrium $\left(\chi^{2}=388.24\right.$, 1 d.f. $\left.=1, P=2 \times 10^{86}\right)$.

All three groups had similar allele and genotype frequencies (Table 2). When the study groups were stratified by obesity and age at examination, the 
Table 1 Clinical characteristics according to study group.

\begin{tabular}{lccc}
\hline Characteristic & $\begin{array}{c}\text { Non-diabetic } \\
\text { controls }\end{array}$ & $\begin{array}{c}\text { Type 1 diabetes } \\
\text { patients }\end{array}$ & $\begin{array}{c}\text { Type 2 diabetes } \\
\text { patients }\end{array}$ \\
\hline$n$ & 163 & 181 & 215 \\
Females (\%) & 57.4 & 53.0 & 47.9 \\
Age at examination (years) & $52.55 \pm 17.97$ & $36.2 \pm 7.1$ & $62.3 \pm 5.4$ \\
Age at diagnosis (years) & & $10.9 \pm 6.2$ & $49.7 \pm 6.2$ \\
Duration of diabetes (years) & $25.97 \pm 4.96$ & $25.4 \pm 7.2$ & $12.7 \pm 5.7$ \\
Body mass index (kg/m ${ }^{2}$ ) & & $24.96 \pm 4.29$ & $31.74 \pm 5.1$ \\
Receiving insulin (\%) & & 100.0 & 61.7 \\
\hline
\end{tabular}

All data are expressed as means \pm S.D. $n$, number of individuals. The high proportion of insulin-treated type 2 diabetes patients was related to the relatively long mean duration of their diabetes.

similarity remained in all strata (data not shown). To examine whether the risk of diabetes was peculiar to a joint effect of both amino acid variants of DBP, the estimated frequencies of two locus haplotypes (see Methods) were also compared and found to be similar in all study groups (Table 3 ).

The Asp-Thr haplotype corresponds to the $\mathrm{Gc}_{1 \mathrm{f}}$ electrophoretic variant, which in the homozygous state has been reported to be associated with quantitative prediabetic traits $(9,10)$. The frequency of homozygotes for this haplotype was similar in all three groups: $3.0 \%$ $(n=5)$ in controls, $3.3 \%(n=6)$ in type 1 patients, and $1.9 \%(n=4)$ in type 2 patients. Thus the frequencies of this variant were similar in all our groups and similar to the published data on white populations (18)

To test the hypothesis that variants of DBP may influence some prediabetic traits, we analysed the fasting plasma glucose and body mass index according to genotypes at both loci in the control group. No difference was found between the carriers of different genotypes (data not shown).

\section{Discussion}

In contrast to several previous observations, this study showed no association between two amino acid variants of vitamin D-binding protein and the risk of type 1 or type 2 diabetes in a white population $(9-13)$. The following discussion of possible explanations for the discrepant results will deal separately with type 1 and type 2 diabetes.

Type 2 diabetes has a complex etiology. Any abnormalities in insulin secretion that are associated with these polymorphisms in the DBP gene may assume an important role only in the presence of environmentally or genetically determined insulin resistance (19). It is important to note that reported associations with the DBP polymorphism were observed in non-white populations $(9-12)$. There have been no reports of association of the DBP polymorphisms with prediabetic traits or type 2 diabetes in white Caucasian populations. Thus it is possible that the effect of these variants of the DBP gene on the development of type 2 diabetes is peculiar to non-whites. It is interesting that the prevalence of homozygotes for the Asp-Thr haplotype, previously reported to be associated with quantitative prediabetic traits, is about seven to eight times greater in Pima Indians than in white populations $(9,18)$.

In whites, only one study found an association between the DBP polymorphisms and the risk of type 1 diabetes (13). As the association had only nominal significance and that disappeared after adjustment for multiple comparisons, the finding may have been a false positive (type 1 error).

Finally, the shortcomings of our study design should be considered. Although our study had enough power to detect a large or moderate impact of these polymorphisms on the risk of diabetes, it was too small to

Table 2 DBP allele and genotype distributions in non-diabetic controls, and patients with type 1 or type 2 diabetes.

\begin{tabular}{|c|c|c|c|c|c|c|c|}
\hline \multirow[b]{2}{*}{$\begin{array}{l}\text { Codon } 416 \\
\text { Controls } \\
\text { Type } 1 \text { patients } \\
\text { Type } 2 \text { patients }\end{array}$} & \multicolumn{3}{|c|}{ Allele } & \multicolumn{4}{|c|}{ Genotype } \\
\hline & $\begin{array}{c}\text { Asp } \\
149(45.7) \\
162(44.8) \\
184(42.8)\end{array}$ & $\begin{array}{c}\text { Glu } \\
177(54.3) \\
200(55.2) \\
246(57.2)\end{array}$ & $\begin{array}{c}\chi^{2}=0.69 \\
2 \text { d.f. } \\
P=0.71\end{array}$ & $\begin{array}{l}\text { Asp/Asp } \\
32(19.6) \\
41(22.7) \\
37(17.2)\end{array}$ & $\begin{array}{l}\text { Asp/Glu } \\
85(52.2) \\
80(44.2) \\
110(51.2)\end{array}$ & $\begin{array}{l}\text { Glu/Glu } \\
46(28.2) \\
60(33.1) \\
68(31.6)\end{array}$ & $\begin{array}{c}\chi^{2}=3.6 \\
4 \text { d.f. } \\
P=0.42\end{array}$ \\
\hline $\begin{array}{l}\text { Codon } 420 \\
\text { Controls } \\
\text { Type } 1 \text { patients } \\
\text { Type } 2 \text { patients }\end{array}$ & $\begin{array}{c}\text { Thr } \\
229(70.3) \\
266(73.5) \\
302(70.2)\end{array}$ & $\begin{array}{c}\text { Lys } \\
97(29.7) \\
96(26.5) \\
128(29.8)\end{array}$ & $\begin{array}{c}\chi^{2}=1.25 \\
2 \text { d.f. } \\
P=0.53\end{array}$ & $\begin{array}{l}\text { Thr/Thr } \\
82(50.3) \\
95(52.5) \\
104(48.4)\end{array}$ & $\begin{array}{l}\text { Thr/Lys } \\
65(39.9) \\
76(42.0) \\
94(43.7)\end{array}$ & $\begin{array}{l}\text { Lys/Lys } \\
16(9.8) \\
10(5.5) \\
17(7.9)\end{array}$ & $\begin{array}{c}\chi^{2}=2.7 \\
4 \text { d.f. } \\
P=0.60\end{array}$ \\
\hline
\end{tabular}

Values are number (\%). 
Table 3 Distribution of haplotypes defined by variants at codons 416 and 420 of DBP as estimated by gene counting (see Methods), according to study group.

\begin{tabular}{lccc}
\hline Haplotype & Controls & $\begin{array}{c}\text { Type 1 diabetes } \\
\text { patients }\end{array}$ & $\begin{array}{c}\text { Type 2 diabetes } \\
\text { patients }\end{array}$ \\
\hline Asp-Thr & $52(16.0)$ & $68(18.8)$ & $59(13.7)$ \\
Asp-Lys & $97(29.7)$ & $94(26.0)$ & $125(29.1)$ \\
Glu-Thr & $177(54.3)$ & $198(54.7)$ & $243(56.5)$ \\
Glu-Lys & $0(0)$ & $2(0.5)$ & $3(0.7)$
\end{tabular}

Values are number (\%).

$\chi^{2}=6.58$ with 6 d.f.; $P=0.367$.

detect weak effects. As a case-control study design may give spurious results attributable to population stratification, including negative findings such as were found in this study, additional studies may be necessary to exclude the possibility of type 2 error.

\section{Acknowledgments}

This research was supported by NIH grants DK-47475 and DK-36836.

TK and MTM contributed equally to the work.

\section{References}

1 Norman AW. The vitamin D endocrine system: identification of another piece of the puzzle. Endocrinology 19941341601 A$1601 \mathrm{C}$

2 Baynes KC, Boucher BJ, Feskens EJ \& Kromhout D. Vitamin D, glucose tolerance and insulinaemia in elderly men. Diabetologia 199740 344-347.

3 Boucher BJ, Mannan N, Noonan K, Hales CN \& Evans SJ. Glucose intolerance and impairment of insulin secretion in relation to vitamin D deficiency in east London Asians. Diabetologia 199538 1239-1245.

4 Mathieu C, Laureys J, Sobis H, Vandeputte M, Waer M \& Bouillon R. 1,25-Dihydroxyvitamin D3 prevents insulitis in NOD mice. Diabetes 199241 1491-1495.

5 McDermott MF, Ramachandran A, Ogunkolade BW, Aganna E. Curtis D, Boucher BJ et al. Allelic variation in the vitamin D receptor influences susceptibility to IDDM in Indian Asians. Diabetologia $199740971-975$.

6 Hitman GA, Mannan N, McDermott MF, Aganna E, Ogunkolade $\mathrm{BW}$, Hales $\mathrm{CN}$ et al. Vitamin $\mathrm{D}$ receptor gene polymorphisms influence insulin secretion in Bangladeshi Asians. Diabetes 199847 688-690.

7 Pratley RE, Thompson DB, Prochazka M, Baier L, Mott D, Ravussin E et al. An autosomal genomic scan for loci linked to prediabetic phenotypes in Pima Indians. Journal of Clinical Investigation 1998101 1757-1764.

8 Nykjaer A, Dragun D, Walther D, Vorum H, Jacobsen C, Herz J et al. An endocytic pathway essential for renal uptake and activation of the steroid 25-(OH) Vitamin D. Cell 199996 507-515.

9 Baier LJ, Dobberfuhl AM, Pratley RE, Hanson RL \& Bogardus C. Variations in the vitamin D-binding protein (Gc locus) are associated with oral glucose tolerance in nondiabetic Pima Indians. Journal of Clinical Endocrinology and Metabolism 1998 83 2993-2996.

10 Szathmary EJ. The effect of Gc genotype on fasting insulin level in Dogrib Indians. Human Genetics 198775 368-372.

11 Iyengar S, Hamman RF, Marshall JA, Majumder PP \& Ferrell RE. On the role of vitamin D binding globulin in glucose homeostasis: results from the San Luis Valley Diabetes Study. Genetic Epidemiology 19896 691-698.

12 Kirk RL, Serjeantson SW \& Zimmet P. Genes and diabetes in the Pacific. In Clinicogenic Genesis of Diabetes Mellitus, pp 34-41. Eds Mimura G, Baba S, Goto Y \& Kobberling J. Amsterdam: Excerpta Medica, 1982.

13 Hodge SE, Anderson CE, Neiswanger K, Rubin R, Sparkes RS, Sparkes MC et al. Association studies between Type 1 (insulindependent) diabetes and 27 genetic markers: lack of association between Type 1 diabetes and Kidd blood group. Diabetologia 1983 25 343-347.

14 Cohen SE, Warram JH, Hanna LS, Laffel L \& Krolewski AS. Threshold effect of hyperglycemia on the progression of microalbuminuria in type 1 diabetes. Journal of the American Society of Nephrology 19978 A0521.

15 Harris MI, Hadden WC, Knowler WC \& Bennett PH. International criteria for the diagnosis of diabetes and impaired glucose tolerance. Diabetes Care 19858 562-567.

16 The Expert Commitee on the Diagnosis and Classification of Diabetes Mellitus. Report of the Expert Commitee on the Diagnosis and Classification of Diabetes Mellitus. Diabetes Care 199720 1183-1197.

17 Doria A, Warram JH \& Krolewski AS. Genetic predisposition to diabetic nephropathy. Evidence for a role of the angiotensin Iconverting enzyme gene. Diabetes 199443 690-695.

18 Braun A, Bichlmaier R \& Cleve H. Molecular analysis of the gene for the human vitamin-D-binding protein (group-specific component): allelic differences of the common genetic GC types. Human Genetics 199289 401-406.

19 Kahn CR. Insulin action, diabetogenes, and the cause of type II diabetes. Diabetes 199443 1066-1082.

Received 26 February 1999

Accepted 19 July 1999 